\title{
Filosofando com Miguilim: questões filosóficas em Campo geral, de Guimarães Rosa
}

Zama Caixeta Nascentes. E-mail: zcaixeta@utfpr.edu.br Mestre em Filosofia. Psicanalista. Profo da UTFPR, campus Curitiba

Resumo: acompanharemos os ciclos de desenvolvimento de Miguilim aproximando os problemas enfrentados por ele com esta questão filosófica: o fundamento dos nossos juízos bonito/feio, certo/errado. Ela se desdobra nesta outra, não menos filosófica: a validade ou não das categorizações dicotômicas com que apreendemos a realidade, já que a divisão é da lógica e não da realidade. Quatro episódios da trajetória do menino ocuparão o centro de nossa análise: discussão se o Mutúm é lugar bonito ou feio; desejo de obter aprovação e evitar censura ao atravessar por entre vacas; vontade de saber se é malfeito ou bem-feito entregar à Mãe o bilhete de Tio Terêz; luto da morte do Dito e seu fracasso de tentar encontrar o vivo no morto.

Palavras-chave: Campo geral, Filosofia, Literatura, fundamento do juízo, ética.

\section{Introdução}

Aproveitamos o lançamento da Edição Comemorativa 50 anos de Corpo baile para retornar à obra e lê-la no formato da primeira edição, dois volumes. A partir da terceira, 1965, a obra tripartiu-se em Manuelzão e Miguilim, Noites no sertão e No urubuquaquá, No Pinhém. Entre elas houve a segunda, de 1960, única em um único volume, feitio desaprovado pelo autor pois "teve de ser de tipo minúsculo demais, composição cerrada. E o preço caro, além de não ficar o livro convidativo." (ROSA, 2003, p. 119-120).

A opção por Campo geral justifica-se pela impressão inicial que tivemos de que a busca de Miguilim, no caso da entrega do bilhete, coincidia com a de toda uma longa tradição filosófica moderna: a procura pelo fundamento sobre o qual repousam as distinções de vício e virtude. No léxico do personagem: saber se o que se vai fazer é malfeito ou bem-feito. Relendo o conto sob essa ótica, constatamos que a questão não se restringia àquele episódio. Ramificava-se para outros e assumia novos contornos, mas mantinha o núcleo: as condições de possibilidade dos juízos. Uma segunda justificativa é a natureza das nossas outras leituras do conto, focada no trabalho de Guimarães com a linguagem. Já que líamos uma nova edição, queríamos uma outra leitura, conduzidos agora por uma preocupação temática de viés filosófico e não por indagações estilísticas - no que é possível separar uma da outra, para efeitos de pesquisa literária.

Da tradição filosófica, evitamos reconstituição que soasse a "fundamentação teórica". Apresentar as linhas gerais do pensamento de Hume e Kant e depois ir a um conto extenso como o de Guimarães faria ranger os dentes de qualquer estudioso dos filósofos e morder a língua os pesquisadores do escritor. Teríamos mais censura que aprovação. Limitamo-nos, pois, a citar dos pensadores o indispensável à compreensão dos nossos argumentos. Corremos o risco de censura por quem está habituado às revisões teóricas. Paciência! Paga-se um preço por se passar por pastos cheios de tão bravos bois... 
Por fim, guiamo-nos por aquilo que chamamos de "ciclos" na vida de Miguilim. Mudanças na natureza (alternância sol/chuva, passagem de bandos de maitacas), adoecimentos (do Miguilim e do Dito), chegadas de alguns personagens (seo Deográcias, seo Aristeu, Luisaltino, mano Liovaldo e tio Osmundo), partidas de outros (Tio Terêz, Vovó Izidra) marcam a conclusão de um ciclo e o início de outro. No entanto, ao invés de ir buscar nas tradições míticas ou nas teorias que delas tratam o significado da própria idéia de "ciclo" ou de "desenvolvimento/iniciação", nossa análise acompanhará sempre a mesma questão: o aprendizado do personagem de que não há uma regra áurea que permite a todos julgar todos os casos de um mesmo modo.

\section{1- Entre o bonito e o feio: o começo do que está por vir}

O início de Campo geral narra uma viagem: “Miguilim tinha oito anos. Quando completara sete, havia saído dali, pela primeira vez: Tio Terêz levou-o a cavalo, à frente da sela, para ser crismado no Sucurijú, por onde o bispo passava." (p. 11). Abre-se um novo ciclo na vida do protagonista. Sua idade corresponde ao número ${ }^{[1]}$ dos sacramentos previstos pelo Catolicismo para marcar a vida do crente em momentos decisivos; o da crisma indica a maturidade da fé (o crismando faz sua a fé que, no batismo, era dos outros) e por ele o cristão recebe os dons do Espírito Santo - um deles o discernimento. Sua saída dali é sua primeira viagem; e viagem em Guimarães é antes psicocartografia que geografia, com o personagem desentranhando dos seus mapas internos outras coordenadas para o viver ${ }^{[2]}$. Sua posição "à frente da sela" amplia-lhe o campo de visão, "tanta coisa podendo ver" (p. 42) - o que não ocorreria caso estivesse na garupa, a avistar apenas as costas do Tio - não só no sentido físico mas sobretudo no psíquico, por ouvir opiniões diferentes sobre o Mutúm que acabam alterando-Ihe a percepção (visão) do lugar onde residia. Tamanha importância de

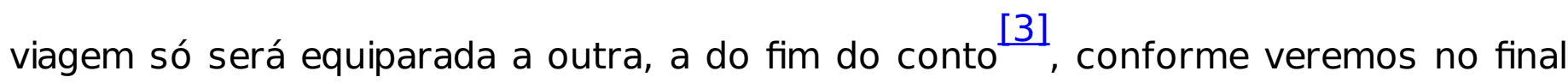
deste trabalho.

No novo ciclo, Miguilim aprenderá que bonito e feio não são qualidades presentes nos objetos mas sim conceitos empregados para descrever modos pelos quais os percebemos. Prepara-se para o que está por vir no episódio dos bilhetes, no qual malfeito e bem-feito não são qualidades da conduta e sim modos distintos de diversas pessoas avaliarem o feito. Na ida ao Sucurijú, ouvira de alguém que já estivera no Mutúm que o lugar era bonito. Parecer diferente tinha sua mãe, "se doía de tristeza de ter de viver ali" (p. 11). Tomando como verdade sobre o Mutúm o dito do outro, Miguilim quis comunicá-la à mãe:

Quando voltou para casa, seu maior pensamento era que tinha a boa notícia para dar à mãe: o que o homem tinha falado - que o Mutúm era lugar bonito... A mãe, quando ouvisse essa certeza, havia de se alegrar, ficava consolada. Era um presente; e a idéia de poder trazê-lo desse jeito de cór, como uma salvação, deixava-o febril até nas pernas (...) e assim que pôde estar com ela só, abraçou-se a seu pescoço e contou-lhe, estremecido, aquela revelação. A mãe não Ihe deu valor nenhum (...) No fundo de seu coração, ele não podia, porém, concordar, por mais que gostasse dela: e achava que o moço tinha falado aquilo era que estava com a razão. Não porque 
ele mesmo Miguilim visse beleza no Mutúm - nem ele sabia distinguir o que era um lugar bonito e um lugar feio. Mas só pela maneira como o moço tinha falado: de longe, de leve, sem interesse nenhum; e pelo modo contrário de sua mãe - agravada de calundú e espalhando suspiros, lastimosa. No começo de tudo, tinha um erro - Miguilim conhecia, pouco entendendo. (p. 12-13).

O que ele tinha como "certeza", "aquela revelação", choca-se com o olhar da mãe, para quem o Mutúm era lugar feio e triste. O termo "revelação" não é gratuito, pois Miguilim acabava de chegar do Sucurijú, onde fora crismar-se; migrado para um contexto não religioso, o substantivo despoja-se do seu sentido teológico (na crisma, o Espírito Santo, se não se revela ao fiel, pelo menos desvela-se, dando-se na forma dos seus dons concedidos ao sacramentado) e veste-se de significação epistemológica: o saber de Miguilim acerca do Mutúm. O menino quer dividir com a mãe o que the foi revelado. Entretanto, a mãe "não the deu valor nenhum". Ora, sabemos, pela correspondência de Guimarães com seu tradutor italiano de Corpo de baile que "você já notou, que, como eu, os meus livros, em essência, são 'anti-intelectuais' - defendem o altíssimo primado da intuição, da revelação, da inspiração sobre o bruxolear presunçoso da inteligência reflexiva, da razão, a megera cartesiana." (ROSA, 2003, p. 90: destaque nosso). É essa revelação que o autor faz chegar até seu personagem, crismando-o. A mãe não se deixa contagiar pelo revelado por Miguilim, que se vê dividido entre o julgamento estético sentenciado por dois adultos. Diante da tristeza da mãe e do juízo dela, a certeza apanhada durante a viagem da crisma esboroa-se. 0 bonito do Mutúm desvelado pelo moço volta a velar-se pelo véu do juízo da mãe. Logo, nem mesmo a Revelação permite discernir o bonito do feio.

E nem a razão. No excerto em foco, o que leva Miguilim a dar crédito à fala do moço e julgar que ele está com a razão não é uma cascata de verdades às Meditações de Descartes - um princípio fundando outro, uma idéia, clara e distinta, concatenandose à outra - e sim "só pela maneira como o moço tinha falado: de longe, de leve, sem interesse nenhum". Se o bonito não está nas coisas e sim no sujeito que as percebe, também a verdade não se encontra no conteúdo das proposições nem no rigor dos conceitos trocados entre os interlocutores e sim no modo de falar, no entôo da voz. Motivo idêntico está na recusa de Miguilim em anuir ao ponto de vista da mãe: perceber que o juízo dela sobre a beleza do Mutúm vem numa voz "agravada de calundú e espalhando suspiros, lastimosa". Não é de se surpreender que "Miguilim conhecia, pouco entendendo", já que sua certeza foi abalada pela frieza com que a mãe recebeu a notícia dada por ele; sua revelação não a tocou. No Domingo, o problema ainda o atordoava, levando-o a procurar em Tio Terêz o ponto de Arquimedes: " - Tio Têrez, o senhor acha que o Mutúm é lugar bonito ou feioso? / - Muito bonito, Miguilim; uai. Eu gosto de morar aqui..." (p. 14). O que Tio Terêz não confessou - e nem Miguilim conjeturou - é que o juízo de Terêz também não se funda na razão e sim no sentimento: acha bonito o Mutúm e gosta de ali morar por ser aí que reside a cunhada Nhanina, mãe de Miguilim, e por quem Terêz é apaixonado.

Conhecer o bonito para distingui-lo do feio é tarefa tão complexa quanto discernir o certo do errado. Mas não só a dificuldade de discernimento aproxima esses pares de conceitos; em Campo geral eles mesclam-se, agrupam-se a outros pares, 
alegria/tristeza, por exemplo. É assim que mãe é bonita e triste, "Mas sua mãe, que era linda e com cabelos pretos e compridos, se doía de tristeza de ter de viver ali." (p. 11); Miguilim, na crise de héctica, relembra as sujices ensinadas pelo Patorí e pensa "de tão feio tudo era bonito" (p. 56) e, no desfecho do conto, sente tamanha confusão de sentimentos que "Nem sabia o que era alegria e tristeza." (p. 133); Drelina "era bonita de bondade" (p. 58); Chica diz de Miguilim: " - Você nasceu em dia-de-sexta com os pés no sábado: quando está alegre por dentro é que está triste por fora..." (p. 62). Não é por acaso que Miguilim, no ciclo de vida iniciado aos sete anos com a ampliação da vista por ir ao Sucurijú à frente da sela de Tio Terêz e receber um sacramento que the ilumina o espírito com os dons do Espírito Santo, começa a enxergar a mistura do certo e do errado, do malfeito e do bem-feito: "Com a aflição em que estivera, de poder depressa ficar só com a mãe, para Ihe dar a notícia, Miguilim devia de ter procedido mal e desgostado o pai, coisa que não queria, de forma nenhuma, e que mesmo agora largava-o num atordoado arrependimento de perdão." (p. 13). Ao desejar revelar à mãe o belo materializado no Mutúm, Miguilim cria o errado, comete um malfeito, ainda que não o quisesse. Fundem-se o bonito (tema da conversa com a mãe), o malfeito (procedeu mal, não dando atenção a Pai, “Este menino .... parece que nem tem estima por mim, não quer saber da gente." - p. 13) e o bem feito (transmitir à mãe a notícia de que o Mutúm é belo e, com isso, atenuar-lhe a tristeza). Como se não bastasse, há ainda a constatação de que o mal proceder era "coisa que não queria" e que ao bom proceder desejado (alegrar a mãe com a revelação da beleza do Mutúm) não se sucedeu um bem: "A mãe não the deu valor nenhum." Realmente, aturdidas questões, "embaraçadas em sua cabecinha" (p. 11).

Com vista tapada e estorvos na cabecinha ficou Miguilim depois de um bom proceder ceder lugar a um mal procedimento, a exemplo do vivido no retorno do Mutúm. Referimo-nos ao episódio com o Menino-Grande. Apesar de o conto não dar a etiologia da doença nas vistas, por uma de suas lembranças de antes do Mutúm sabemos que Miguilim foi apedrejado por um menino a quem tentava agradar. À pedrada seguiu-se a turvação da vista: “Miguilim repetia, só para agradar o meninogrande. E aí o Menino-Grande levantava com as duas mãos uma pedra, fazia uma careta pior (...) Depois, era só uma confusão,(...) e Miguilim não podia enxergar, uma coisa quente e peguenta escorria-lhe da testa, tapando-lhe os olhos." (p. 14). No bem feito pretendido por Miguilim o Menino-Grande viu um malfeito - tanto quanto Pai ao julgá-lo, " - Este menino é um mal-agradecido."

O acontecimento acima envolvendo Pai não só mostra a mistura do bonito com o malfeito mas também a dificuldade de separar o malfeito do bem-feito. Da mesma forma que no episódio com o Menino-Grande, o vivido por Miguilim com Pai traz à tona o intercâmbio do certo com o errado. É difícil proceder bem porque a intenção de agir bem não garante uma ação boa, conforme mostram as duas cenas anteriores. Por isso a pergunta de Miguilim, que acompanharemos agora: como distinguir o malfeito do bem feito? 


\section{2- Entre o malfeito e o bem-feito: o que veio}

A relação entre acerto e erro de nossa conduta e a busca de sua aprovação pelos demais são temas recorrentes na filosofia moral moderna. Miguilim defronta-se com a questão em dois episódios de sua vida: travessia por entre vacas e entrega do

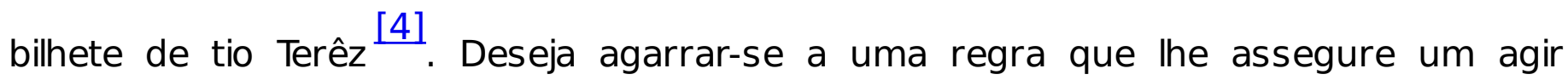
irreprochável. Comecemos pelo primeiro:

A coisa mais difícil que tinha era a gente poder saber fazer tudo certo, para os outros não
ralharem, não quererem castigar. De primeiro, Miguilim tinha medo dos bois, das vacas
costeadas. Pai bramava, falava: - 'Se um sendo medroso, por isso o gado te estranha, rês sabe
quando um está com pavor, qualquer receiozinho, então capaz mesmo que até a mansa vira
brava, com vontades de bater...' Pois isso, outra vez, Miguilim sabia que a gente não tivesse
medo não tinha perigo, não se importou mais, andou logo por dentro da boiada, duma boiada
chegada, poeira de boi. Daí, foi um susto, veio Pai, os vaqueiros vieram, com as varas,
carregaram com ele Miguilim pra o alpendre, passavam muito ralho. '- Menino, diabo, demonim!
Tu entra no meio desse gado bruto, que é outro, tudo brabeza dos Gerais?!. Sei como não
sentaram chifre, não te espisaram!...' De em diante, Miguilim tudo temeu de atravessar um
pasto, a tiro de qualquer rês, podia ser brava podia ser mansa, essas coisas. Mas agora Miguilim
queria merecer paz dos passados, se rir seco sem razão. Ele bebia um golinho de velhice. (p.
71).

A pergunta é como "poder saber fazer tudo certo", acrescentada da finalidade: obter a aprovação. Se para uma situação comum a uma criança criada numa fazenda dedicada à pecuária - atravessar por entre bois e vacas - os adultos não são referência do que é certo ou errado, por ser móvel o parecer deles sobre o correto proceder naquele contexto, não o será para uma complexa e inusitada como a da entrega do bilhete. De fixo - assunto das epígrafes de Corpo de baile - não há nada, nem a distinção entre "vaca brava" e "vaca mansa", pois no conselho de Pai já estava a advertência, "qualquer receiozinho, então capaz mesmo que até a mansa vira brava, com vontades de bater". O cálculo feito por Miguilim a partir da orientação dos adultos gerou resultado diverso (censura) do pretendido (aprovação). Sua conduta foi reprovada nas duas circunstâncias (quando não passou por entre as reses e quando passou), indicação suficiente da insuficiência dos dois conselhos norteadores da conduta do menino. Ele saiu do episódio sem saber qual o agir certo ao atravessar por entre vacas, permanecendo na dúvida quanto a aprovação ou censura de sua conduta. Essa dúvida o acompanhará até a vida adulta, conforme se lê nesta passagem de Buriti, quando ele está vacinando o gado de nhô Gualberto Gaspar: "Sempre, surdamente, Miguel guardava temor de estar ocioso e de errar. Um horror de que se errasse, de que ainda existisse o erro. A mais, como se de repente, de alguém, de algum modo, na viração do dia, na fresca da tarde, estivesse para se atirar contra ele a violência de uma reprovação, de uma censura injusta." (p. 648). Na conclusão do episódio de entrebois, "tudo temeu de atravessar um pasto, a tiro de qualquer rês, podia ser brava podia ser mansa".

"Podia ser brava podia ser mansa": não se trata, portanto, de ser brava ou ser mansa, um ser fixamente estabelecido. Braveza ou mansidão são possibilidades existentes no agir dos bovinos tanto quanto malfeito e bem-feito são possíveis juízos 
para a conduta dos humanos. Da mesma forma que "vaca" desliza entre "mansa" e "brava", podendo, conforme as circunstâncias ou o estado do passante, ser ora uma ora outra coisa, também "feito" desloca-se entre "bem" e "mal" combinando-se com um ou com outro e disso resultará a aprovação ou a censura da ação.

O tema da (i)mobilidade não só nas coisas mas também nas palavras reaparece em Buriti na cena do serão da despedida de Miguel do Buriti Bom: “Glorinha é bela. Dona Lalinha é bonita. Mas as palavras não se movem tanto quanto as pessôas: um podia, não menos verdade, dizer - Dona Lalinha é bela, Glorinha é bonita..." (p. 636). Nega-se a mobilidade, "as palavras não se movem", mas logo ela é admitida, "um podia, não menos verdade, dizer - Dona Lalinha é bela, Glorinha é bonita". Logo, o belo não está em nenhuma delas mas na operação lingüística de deslizamento das palavras durante a enunciação do juízo, como o bravo e o manso de agora pouco e o bem-feito e malfeito de daqui a pouco e, no próprio exemplo em foco, o "não se mover" e o "mover-se".

E deslizar é justamente a ação de Miguilim por entre as vacas. É, de fato, as vacas dando-Ihe lições filosóficas; afinal, "Quem lida com eles [vacas e cavalos] aprende muito para sua vida e a vida dos outros." (ROSA, 1995, p. 32). Por isso o arremate do episódio, "Ele bebia um golinho de velhice" ${ }^{[5]}$. Na velhice há maiores sabenças; no caso, o saber acerca da mobilidade do "certo" e do "errado".

Há um outro fato notável em que Miguilim aprende com os bois. Referimo-nos ao ensino dado pelo boi Rio-Negro: “Miguilim não queria dizer que agora estava pensando no Rio-Negro: que por que era que um bicho ou uma pessoa não pagavam sempre amor-com-amor, de amizade de outro? Ele tinha botado a mão no touro para agradar, e o touro tinha repontado com aquela brutalidade." (p. 91). Miguilim quis fazer um bem ao boi e este tomou o feito como sendo um mal. O episódio carrega o mesmo sentido do havido entre Miguilim e o Menino-Grande; os dois episódios apontam para a questão que tomamos aqui como central na trajetória de Miguilim: o aprendizado da inexistência de uma regra fixa que possibilite separar bonito de feio, certo de errado, bem feito de malfeito.

No diálogo filosófico, a seguir transcrito, entre Dito e Miguilim, logo após Miguilim interrogar-se sobre o motivo de o touro Rio-Negro ter tomado como maldade a bondade por ele feita (acariciar-lhe a testa), encontra-se, de novo, o tema da dificuldade de ajuizar sobre realidades contínuas e não distintas:

\footnotetext{
Mas, de noite, no canto da cama, o Dito formava a resposta:

- 'O ruim tem raiva do bom e do ruim. Bom tem pena do ruim e do bom... Assim está certo.' ‘ - E os outros, Dito, a gente mesmo?' O Dito não sabia. - 'Só se quem é bronco carece de ter raiva de quem não é bronco; eles acham que é moleza, não gostam... Eles têm medo que aquilo pégue e amoleça neles mesmos com bondades...' ' - E a gente, Dito? A gente?' ' - A gente cresce, uai. O mole judiado vai ficando forte, mas muito mais forte! Trastempo, o bruto vai ficando mole, mole...' (p. 92).
}

Dito reúne tudo numa totalidade indiscernível: 1) "o ruim tem raiva do bom e do ruim", e não só do bom - como na opinião dos outros, "o bronco carece de ter raiva de quem não é bronco" -; 2) "o bom tem pena do ruim e do bom", e não apenas do 
ruim; 3) "O mole judiado vai ficando forte ... trastempo, o bruto vai ficando mole, mole". A favor desse nosso raciocínio há, na mesma página, o relato de que a família foi acordada com a notícia da fuga de Maria Pretinha com o vaqueiro Jé. A fuga atrela-se ao debate anterior: "O vaqueiro Jé era branco, sardal, branquelo. Como é que foi namorar completo com a Maria Pretinha?" (idem). Resumindo: o branco de Jé e o preto de Maria Pretinha misturaram-se, como o feio e o bonito do Mutúm, o bom proceder com Mãe e o mal proceder com Pai, a bondade de Miguilim e a maldade do MeninoGrande, o bravo e o manso nas vacas, a carícia de Miguilim e a brutalidade do touro Rio-Negro.

Já falamos que Campo geral começa com a entrada de Miguilim num novo ciclo. Antes do caso dos bilhetes, o personagem mergulhou num outro, no qual foi introduzido pela consulta de seo Deográcias. Avaliando-lhe a saúde, Deográcias disse: "E, é o que eu digo: p'ra passar a héctico é só facilitar de beirinha" (p. 38). Bastou isso para o menino ver-se já adoentado e com os dias contados. Durante várias páginas, o conto narra esse adoecimento, com Miguilim aos tratos com Deus sobre o morrer. Tudo que enxerga da conduta dos outros interpreta como sendo a confirmação de sua iminente morte. Desse segundo ciclo sairá pelas palavras de um outro consultor, seo Aristeu: “' '- Então eu não sou héctico nem tísico não, seo Aristeu?' ' - Bate na boca por bestagem tão grande que se disse, compadre meu Miguilim: nunca que eu nem não ouvi outra maior. Tísica nem não dá, nestes Gerais, o ar aqui não consente! Vai o que você tem é saúde grande ainda mal empenada...' " (p. 61). Percebendo-se são, Miguilim sente voltar-lhe o apetite, nasce-lhe o desejo de ajudar Pai na roça. Inicia-se então o que chamamos de terceiro ciclo. Ao levar, "num dia-de-manhã bonito, o sol chamachando, estava dado lindo o grilgril das maitacas" (p. 62), o almoço a Pai na roça é que lhe salta no caminho Tio Terêz, entregando-lhe o bilhete e jogando-o num dilema, não mais do morrer ou do viver, do doente ou do sadio e sim do malfeito ou do bem feito:

- Dito, como é que a gente sabe certo como não deve de fazer alguma coisa, mesmo os outros não estando vendo?" “ - A gente sabe, pronto." (...) " - Rosa, quando é que a gente sabe que uma coisa que vai não fazer é malfeito?" " - É quando o diabo está por perto. Quando o diabo está perto, a gente sente cheiro de outras flores..." A Rosa estava limpando açúcar, mexendo no tacho. Miguilim ganhava o ponto de puxa, numa cuia d'água; repartia com o Dito. “ - Mãe, o que a gente faz, se é mal, se é bem, ver quando é que a gente sabe?" “ - Ah, meu filhinho, tudo o que a gente acha muito bom mesmo fazer, se gosta demais, então já pode saber que é malfeito..." O vaqueiro Jé descascava um ananás branco, a eles dava pedaço. " - Vaqueiro Jé: malfeito como é, que a gente se sabe?" “ - Menino não carece de saber, Miguilim, Menino, o todo quanto faz, tem de ser mesmo é malfeito..." Vaqueiro Salúz aparecia tangendo os bezerros, as vacas que berravam acompanhavam. Vaqueiro Salúz vinha cantando bonito, ele era valente geralista. A ele Miguilim perguntava. “ - Sei se sei, Miguilim? Nisso nunca imaginei. Acho quandos os olhos da gente estão querendo olhar para dentro só, quando a gente não tem dispor para encarar os outros, quando se tem medo das sabedorias... Então, é mal feito." Mas o Dito, de ouvir, ouvir, já se invocava. " - Escuta, Miguilim, esbarra de estar perguntando, vão pensar você furtou qualquer trem de Pai." "- Bestagem. O cão que eu furtei algum!" " - Olha: pois agora que eu sei, Miguilim. Tudo quanto há, antes de se fazer, às vezes é malfeito; mas depois que está feito e a gente fez, aí tudo é bem-feito..." O Dito, porque não era com ele. Fosse com ele, desse jeito não caçoava. (p. 69-70)

Do Dito, alcança duas discrepantes respostas. Na primeira, Dito sustenta a 
existência da distinção entre certo e errado e o nosso conhecimento dela, embora não aponte o fundamento que nos permitiria isso. Na segunda, nega existir regra a priori, pois se antes de se fazer é malfeito e depois que se faz "aí tudo é bem-feito" é porque não há, antes de agir, uma regra que possibilite antever a aprovação ou a censura. É necessário correr o risco e por isso o errado (o "malfeito") é omitir-se, à espera do que não virá (a norma imóvel conforme a qual se pode agir sempre com acerto) e o certo (bem feito) é agir, mesmo sabendo do risco corrido (aprovação ou censura).

E da tênue linha que separa (ou amarra) o certo e o errado Dito muito bem sabia. Ele protagoniza o caso da árvore-de-flor, no qual malfeito e bem feito amalgamam-se por inteiro. A árvore crescia rápido, seo Deográcias recomendou o corte alegando que quando ela passasse do telhado alguém da família morreria. Isso coincide com a crise de Miguilim de achar à porta sua morte; logo, o menino assusta-se mais ainda. Apesar do conselho de graça, Pai não o acatou. Dilema: deixar a árvore crescer, obedecendo Pai, ou cortá-la, cedendo a Deográcias? Miguilim precisa decidir, pois julga ser ele a pessoa a morrer. Socorre-o Dito: "ele chamou o vaqueiro Salúz, disse que para botar no chão, mandado de pai." (p. 52). Pai foi desobedecido. Castigo certo: "Quando os outros viram, todos ficaram assustados, temor do pai, diziam o Dito ia apanhar de tirar sangue." (idem). Temor confirmado: "Pai chegou, soube da árvore cortada, chamou o Dito: “ - Menino, eu te amostro! Que foi que mentiu, que eu tinha mandado sentar facão na árvore-de-flôr?!" (idem). O feito de Dito foi bem feito se o olharmos na perspectiva de Miguilim: " - Dito, alegria minha maior se alguém terminasse com a árvore-de-flor, um vento forte derribasse...". No entanto, tomado sob a perspectiva do Pai, um malfeito, já que o pai acusa Miguilim de mentir. Nesse julgamento moral, Dito faz uso da palavra: “ - Ah, Pai, ressonhei que o que se disse, se a árvore danasse de crescer, mais o senhor é que é o dono da casa, agora o senhor pode bater em mim, mas eu por nada não queria que o senhor adoecesse, gosto do senhor, demais..." (idem). E Pai vira pelo avesso seu parecer: "E o pai abraçou o Dito, dizia que ele era menino corajoso e com muito sentimento, nunca que mentia." (p. 52-53 - grifo nosso). O episódio baratina Miguilim: "Miguilim não entendia o sopro daquilo; pois até ele, que sabia de tudo, dum jeito não estava acreditando mais no que fora: mas achando que o que o Dito falou com o pai era que era a primeira verdade." (p. 53). Malfeito ou bem feito não depende do feito e sim do dito. Se bem dito, bem feito e bendito; se mal dito, malfeito e maldito.

Dos quatro adultos interrogados, Miguilim obtém quatro diferentes respostas.

A de Rosa parece ser simples e direta, não fosse tão embaraçoso diferenciar Tinhoso e Deus - tão difícil quanto discriminar o malfeito do bem feito, o feio do bonito -, dificuldade sintetizada na sentença da moça: "Quando o diabo está por perto, a gente sente cheiro de outras flores...". De fato, o Capiroto não fede tanto quanto se sinta; estando por perto, o certo cheiro nem sempre será de enxofre, às vezes podendo ser de rosa, assim como pode ser do Rosa (e não da Rosa) a resposta aparentemente simples. Não é fato desconhecido que "João Guimarães Rosa utiliza diversos anagramas por sua obra afora" (MACHADO, 2003, p. 95); aqui trata-se antes 
de gramas de sentido, possibilidades de significação condensadas no nome da personagem e da referência a "cheiro de outras flores". As outras flores sentidas? O Rosa, ocultado pela Rosa, que esconde a rosa (flor) que pode amoitar o Não-sei-quediga. A condensação no nome Rosa vê-se também na passagem em que Miguilim, descabeceado com a sua possível morte (entendeu assim a fala de seo Deográcias com Pai e Mãe) indaga de Rosa o sentido da palavra héctico. Rosa: " - Menino, fala nisso não. Héctico é tísico, essas doenças, derrói no bofe, pessoa vai minguando magra, não esbarra de tossir, chega cospe sangue..." (p. 46). Muita conhecença médica para quem vivia às voltas com tachos, panelas, sabugos e tições. No dizer de Paulo Rónai: "A falta de separação entre personagens e autor faz que complicados conteúdos intelectuais venham a revestir-se de modismos populares e a cheirar a preciosismo. Como quem vence uma aposta, o autor esconde, aqui e ali, nas meditações de seus sertanejos, um pensamento de Platão ou de Plotino." (RONAI, 2006, p. 23). O dito de Rosa, "Quando o diabo está perto, a gente sente cheiro de outras flores" pode ser assim entendido: quando a Rosa está perto, a gente sente cheiro de outras rosas: escutamos o Rosa.

A de Mãe soa simples, fazendo repousar no gostar o critério de julgamento do malfeito, não tivesse contra si o estorvo que é separar o gostar do não gostar - pólos que se misturam muitas vezes nos personagens de Campo geral, a exemplo do sentido por Miguilim entre alegria e tristeza no final do conto. Não seria diferente o gostar/não gostar. A posição de Mãe é diametralmente oposta à do primeiro Dito, pois apresenta um suporte para a distinção malfeito/bem-feito - o que Dito não fazia: "A gente sabe, pronto.". Filosoficamente, a primeira posição de Dito diferencia-se da de Mãe. A dele aproxima-se da noção kantiana de imperativo categórico da segunda seção da Fundamentação da metafísica dos costumes: a lei moral ditada à vontade pela razão ordena incondicionalmente uma ação, permitindo saber, antes de agir, se a ação será, do ponto de vista moral $[7]$, bem feita (iniciada por uma vontade determinada pela lei moral) ou malfeita (resultante de uma vontade determinada pelas inclinações). A de Mãe beira à tese defendida por Hume na parte I do Livro III do Tratado da natureza humana: as nossas distinções morais repousam no sentimento e não na razão:

quando declaramos que uma ação ou caráter são viciosos, tudo que queremos dizer é que, dada a constituição de nossa natureza, experimentamos uma sensação ou sentimento de censura quando os contemplamos. O vício e a virtude, portanto, podem ser comparados a sons, cores, calor e frio, os quais, segundo a filosofia moderna, não são qualidades nos objetos, mas percepções na mente. (...) Nada pode ser mais real, ou nos interessar mais, que nossos próprios sentimentos de prazer e desprazer; e se estes forem favoráveis à virtude e desfavoráveis ao vício, nada mais pode ser preciso para a regulação de nossa conduta e comportamento. (p. 509).

Se Hume não reconhecia nenhum papel na razão quando o tema é distinguir vício de virtude, Guimarães também entende que ela não é lá tão senhora de altas luzes, conforme queriam os iluministas: "o cérebro é uma organização muito defeituosa e debilitada. Por isso o homem possui, além do cérebro, o sentimento, o coração, como queira." (ROSA, 1995, p. 54-55: destaque nosso). Defeitos que Miguilim aprende, 
quando está amedrontado com sua morte próxima por estar héctico: "o governo da cabeça era erroso - vinha era toda idéia ruim das coisas que estão por poder suceder!" (p. 47). Num sentir, e não num saber, é que Dante Moreira Leite repousa a decisão de Miguilim de não entregar o bilhete: "nem sabe por que seria errado entregar à mãe um bilhete de Tio Terêz, mas sente que não deveria fazê-lo, e não o faz". (LEITE, p. 265: itálico nosso).

Já a de Jé nega aos meninos qualquer possibilidade de acertar; o que fizerem, malfeito sempre será. Sua resposta nos reconduz ao episódio da travessia por entre vacas. Lá, um dos ralhos ouvidos por Miguilim foi: “ - Menino, diabo, demonim!”. O alinhamento de menino e diabo num só sintagma transforma-os numa mesma série; se o Pé-de-pato malfeito sempre faz, não será diferente com menino, que é "diabo, demonim". Menos ainda com o menino Miguilim, cujo nome, embora anjo, rima com o Cujo, "demonim".

A de Vaqueiro Salúz desconcerta tanto quanto a dos outros. Iremos considerá-la adiante.

A do segundo Dito confirma a incerteza da primeira: " - Olha: pois agora que eu sei, Miguilim.". Se agora é que sabe, antes não sabia; sendo assim, de onde extraiu aquele "A gente sabe, pronto."? Parece que não sabia, tendo antes que aprontar o saber, enquanto Miguilim seguia indagando dos outros adultos. Ora, se o muito ajuizado Dito precisou de tempo para partejar a resposta é porque na pergunta encontram-se as genuínas questões do autêntico filosofar.

Vimos as respostas. Díspares, reiteram o quão profundo foi o indagar de Miguilim e o fracasso a que está condenada sua busca, por não existir uma e sim várias respostas. Seria, no entanto, uma só a pergunta endereçada por ele aos interlocutores? "Nisso nunca imaginei", saluziariam alguns leitores nossos. Confrontemos, pois, as diferentes formulações.

" - Dito, como é que a gente sabe certo como não deve de fazer alguma coisa, mesmo os outros não estando vendo?". Pergunta-se pelo "como" de algo que "não deve de fazer"; no entanto, "como" requer um fazer cujo modo de execução possa ser discutido. Caberia responder se Miguilim formulasse nos padrões de Glória, de Buriti: “ - 'Lala, me conta: há algum jeito de eu poder saber se... se casando com Miguel vai dar certo?'” (p. 767). O "algum jeito de poder saber" equivale ao "como é que a gente sabe". A resposta de Lala, em termos estritamente lógicos, foi a mais exata possível: “ - 'Certo, sobre cem, não tem, não, meu bem, infelizmente... Só depois, você compreende. Corpo com corpo...' - 'É horrível, então! Mas, Lala, é horrível...'” (idem). Se foi horrível para o adulto descobrir essa verdade da condição humana, imagina para a criança, Miguilim...

“ - Rosa, quando é que a gente sabe que uma coisa que vai não fazer é malfeito?". Diferente da anterior, a pergunta recai sobre o "quando"; apesar dessa diferença, assemelha-se a ela. De fato, indagar pelo "quando" (da mesma forma que pelo "como") pressupõe que algo será feito; sabendo-se disso, busca-se conhecer o momento (isto é, "o quando") da ação. Ora, uma "coisa que vai não fazer" não 
ocorrerá e por isso mesmo não correrá sobre nenhum eixo de temporalidade. Conclusão: não cabe perguntar pelo quando ou, no mínimo, já se sabe a resposta: nunca, em tempo nenhum. Outra semelhança com a pergunta anterior: se "vai não fazer", não há feito que possa ser julgado como "malfeito" ou "bem-feito".

“ - Mãe, o que a gente faz, se é mal, se é bem, ver quando é que a gente sabe?". Parece acertada a formulação, não fosse toda a sua força recair no "quando", tanto quanto a construída para Rosa. Da forma como está, a resposta é: só depois de já ter feito, como Lala respondera a Glória - ainda que essa lhe perguntasse pelo “como" e não pelo "quando". De fato, sem algo feito não se pode avaliar como malfeito nem bem feito. No entanto, Mãe, assim como Rosa, ouve no lugar do "quando" o "como" da primeira formulação. Por isso responde sem nenhum pestanejo de dúvida.

“ - Vaqueiro Jé: malfeito como é, que a gente se sabe?". Toda atenção para a pontuação ${ }^{[8]}$ aqui é pouca. Para ser pergunta pelo “como", nos moldes da dirigida antes ao Dito, a vírgula teria de deslizar para trás e obrigar a pausar após o "malfeito": "malfeito, como é que a gente sabe?". Era essa a forma de pontuar a pergunta apontada para Mãe: “Mãe, o que a gente faz, se é mal, se é bem, ver quando é que a gente sabe?". Sabemos aqui o que Miguilim busca compreender: quando saber se é mal ou bem o que se faz. Não seria tal o entendimento se a vírgula viesse antes do quando: “Mãe, o que a gente faz, se é mal se é bem ver, quando é que a gente sabe?". No caso da pergunta a Jé, embora não seja uma interrogação - e menos ainda uma acerca do "como" saber o que é malfeito -, pela resposta do vaqueiro vemos que foi assim que ele a compreendeu e atribuiu ao agir dos meninos uma necessidade até então ausente nos diálogos: "Menino, o todo quanto faz, tem de ser mesmo é malfeito".

Não sendo, pois, uma interrogação é uma afirmação: algo é malfeito. A seqüência, "que a gente SE sabe?" indica esse algo: a gente. Logo, trata-se do espanto de Miguilim de reconhecer que "Homem foi feito assim, barro de Adão não é pedra" ( $p$. 303), na expressão do vaqueiro Delmiro de $A$ estória de Lélio e Lina. Não é, portanto, um indagar acerca do correto modo de diferenciar o certo do errado, de decidir entre o fazer e o não fazer e de avaliar o feito como malfeito ou bem feito. Não houvesse o "se", ainda se poderia tomar por uma busca do fixo que permite julgar malfeito algo que foi feito. Todavia, lá está o “se", desviando-nos dessa racionalizante leitura. Portanto, é uma afirmação interrogativa que traduz o espanto do menino diante da descoberta de que, malfeito como somos, qualquer decisão tomada pode revelar o barro com que fomos amassados - ainda que, conforme relato bíblico, por oleiro divino e que nos soprou seu espírito, o mesmo que Miguilim recebe na crisma no Sucurijú na abertura de Campo geral. Logo, a entrega do bilhete de Tio Terêz para Mãe ou a retenção dele poderá ser um malfeito: se sim, será um malfeito, se analisado sob a perspectiva de Pai; se não, será malfeito, se avaliado sob o ponto de vista de Terêz, a quem Miguilim se sente ligado por dever de lealdade e sentimento de forte bem-querer.

Por fim, a não-pergunta. Para a resposta do Vaqueiro Salúz não há nenhuma formulação. Tudo que lemos é: "A ele Miguilim perguntava.". Ponto final. Nenhuma 
alusão ao conteúdo do perguntado. Conforme argumentamos aqui, indaga-se por outro ponto a cada nova redação; logo, não se pode dar como irrelevante a ausência da pergunta julgando-a já sabida do vaqueiro. Se de Salúz poder-se-ia esperar um

cessar da querela, dado o iluminismo emanado do seu próprio nome ${ }^{[9]}$, frustra-se tal expectativa. Ele sequer imaginara existir o problema, "Nisso nunca imaginei.". Para traduzir a inexistência da questão para Salúz, suprime-se a pergunta do texto. Não há como formulá-la para quem nunca a formulou para si. A luz brotada de Salúz faz série à pouca luz que entra pelos olhos de Miguilim, piticégo. A doença nas vistas simboliza a dificuldade em enxergar a diferença entre o bem-feito e o malfeito; Miguilim anda às apalpadelas, à coleta do que não há: o critério supremo da moralidade (para falarmos kantianamente) que nos dotaria de uma bússola capaz de sempre apontar-nos a conduta certa. A luz de Salúz lhe é salutar, clareando-lhe que a resposta não será captada ao ouvir o discurso do outro e sim ao olhar para si. A resposta de Salúz traz ainda um inusitado "quandos", "Acho quandos os olhos da gente..." $\frac{[10]}{\text {. A forma plural }}$ retoma o "quando" endereçado a Rosa e a Mãe, já que não responderam ao "quando" por Miguilim perguntado e sim ao "como", disparado a Dito.

De igual modo, não ouvimos Miguilim perguntar segunda vez ao Dito. Esse responde porque "já se invocava", não por ser invocado pelo Miguilim para responder. Análoga à de Salúz, a segunda resposta de Dito é um outro "quandos": "Tudo quanto há, antes de se fazer, às vezes é malfeito; mas depois que está feito e a gente fez, aí tudo é bem-feito...". Há aqui duas marcações temporais, remetendo-nos aos dois "quando" postos para Rosa e Mãe. No entanto, ao Dito não fora perguntado, da primeira vez, sobre o quando e sim o como; logo, responde ao que não the foi solicitado - tanto quanto Rosa, Mãe, e ele mesmo, da primeira vez. Cada um responde ao que ouve, não ao que houve de perguntado pelo Miguilim. Ele sente aqui a solidão existencial a que estamos condenados (pois o sentido do que dizemos fica conosco, o vento leva ao outro apenas as palavras - conforme metáfora de Cecília Meireles ${ }^{[11]}$ ) e companheira sua desde a experiência com o morrer após a visita de seo Deográcias: "Ser menino, a gente não valia para querer mandar coisa nenhuma. Mas, então, ele mesmo, Migulim, era quem tinha de encalcar de rezar, sozinho por si, sem os outros, sem demão de ajuda." (p. 43: destaque nosso).

\section{3- $O$ feito. $O$ morto. $O$ vivo: 0 que foi}

Enfim, a decisão: "Tinha pensado tudo que podia dizer e não fazer? Não tinha." (p. 75). Tanto não tinha que Ihe ocorrem mais quatro possibilidades. Uma delas montada sob a forma de uma "estoriazinha", em que figura um Menino do Tabuleirinho. Ora, tabuleiro não só era o objeto em que Miguilim transportava a comida para Pai mas também metáfora do quebra-cabeça em que se encontra: a necessidade de decidir sem ter diante de si nenhuma pista acerca de qual jogada executar e menos ainda a que resultado chegará ao se optar por uma (in)certa jogada: 


\begin{abstract}
- 'Tio Terêz, eu entreguei o bilhete a Mãe, mas Mãe duvidou de me dar a resposta...' Ah, de jeito nenhum, podia não, era levantar falso à Mãe, não podia. Mas então não achava escape, prosseguiu sem auxílio de desculpa, remissão nenhuma por suprir. Sem tempo mais, sem o solto do tempo, e o tamanho de tantas coisas não cabia em cabeça da gente... Ah, meu-deus, mas, e fosse em estória, numa estória contada, estoriazinha assim ele inventando estivesse - um menino indo levando o tabuleirinho com o almoço - e então o que era que o Menino do Tabuleirinho decifrava de fazer? Que palavras certas de falar?! - 'Tio Terêz, Vovó Izidra vinha, raivava, eu rasguei o bilhete com medo d'ela tomar, rasguei miudinhos, tive de jogar os pedacinhos no rego, foi de manhãzinha cedo, a Rosa estava dando comida às galinhas...' - Tio Terêz, a gente foi a cavalo, costear o gado nesses pastos, passarinhos do campo muito cantavam, o Dito aboiava feito vaqueiro grande de toda-a-idade, um boi rajado de pretos e verdes investiu para bater, de debaixo do jacarandá-violeta, ái, o bilhetezinho de se ter e não perder eu perdi...' Mas, aí, Tio Terêz não era de estória, aí ele pega escrevia outro bilhete, dava a ele outra vez; tudo, pior de novo, recomeçava. - 'Tio Terêz, eu principiei querer entregar a Mãe, não entreguei, inteirei coragem só por metade...' Ah, mas se isso, Tio Terêz não desanimava de nada, recrescia naquela vontade estouvada de pessôa, agarrava no braço dele, falava, falava, não desistia nenhum. Nenhum jeito! Agora Miguilim esbarrava, respirava mais um pouco, não queria chorar para não perder seu pensamento, sossegava os espantos do corpo. E não tinha outro caminho, para chegar lá na roça do Pai? Não tinha, não. Miguilim lá ia. la, não se importava. Tinha de ser lealdoso, obedecer com ele mesmo, obedecer com o almoço, ia andando. Que, se rezasse, sem esbarrar, o tempo todo, todo tempo, não ouvia nada do que Tio Terêz falasse, aí andando, rezava, escutava não, ia andando, ia andando... Entrava no mato. Era aquele um mato muito calado. Miguilim rezava, sem falar alto, Deus vaquejava os pequenos e os grandes! E era na volta que o Tio Terêz ia aparecer? Não era. (p. 75-77)
\end{abstract}

Nenhuma das possibilidade o tranquiliza. Miguilim revive a experiência acerca da feíce/belezice do Mutúm, da aprovação/censura quanto ao modo sensato de passar por bois e vacas e do "como" e "quando" saber do malfeito e do bem-feito de um feito. A cada nova resposta que chega, sai para outra nova pergunta, num autêntico exercício do pensar filosófico que nos lembra a máxima de Grande Sertão: Veredas: "Vivendo se aprende; mas o que se aprende, mais, é só a fazer outras maiores perguntas" (p. 378). Na primeira delas constata logo o malfeito que seria: "Ah, de jeito nenhum, podia não, era levantar falso à Mãe, não podia". Pensa até em buscar um caminho alternativo para chegar à roça onde Pai capinava e que o desencontrasse de Tio Terêz. Não havia, no entanto, outro caminho: “Não tinha, não. Miguilim lá ia. Ia, não se importava. Tinha de ser lealdoso, obedecer com ele mesmo, obedecer com o almoço, ia andando.". Aprendeu portanto a lição do Vaqueiro Salúz e olha para dentro de si, "obedecer com ele mesmo"; socorre-lhe também o discernimento vindo da transcendência, põe-se a rezar; afinal, "Deus vaquejava os pequenos e os grandes!".

Finalmente, encontra-se com o tio e, chorando, responde: "Tio Terêz, eu não entreguei o bilhete, não falei nada com Mãe, não falei nada com ninguém! (...) O bilhete está aqui na algibeira de cá, o senhor pode tirar ele outra vez..." (p. 77). A reação de Terêz foi de aprôvo: “ - Miguilim, Miguilim, não chora, não te importa, você é menino bom, menino direito, você é meu amigo! (...) Você é que está certo, Miguilim." (Idem: destacado por nós). Se retornarmos ao episódio dos bois, conseguiu a aprovação do tio; se retrocedermos à pergunta pelo "quando", só conheceu o malfeito ou o bemfeito depois de feito; se regredirmos à indagação pelo "como", só soube o "como saber" ou o "como fazer" depois de agir. Porque ninguém mais ficou sabendo da existência do bilhete, sua ação foi bem feita, porquanto aprovada por Terêz, único capaz de julgá-la posto único a conhecê-la como um ato de Miguilim. O dito de Tio Terêz 
torna bem-feito o feito de Miguilim, como no incidente da árvore-de-flor o dito de Dito. No início do conto, por Tio Têrez Miguilim aprendeu de vez que o Mutúm era bonito; aqui, interagindo com o tio, entendeu que malfeito ou bem feito só se sabe quando já se fez e que não há um "como" que nos habilite a anteciparmo-nos ao fazer para conhecer a aprovação ou a censura da conduta. E censurar ou aprovar é um dizer.

$\mathrm{E}$ o bem-feito pode vir a ser um malfeito, tão entrelaçados encontram-se e tão desenlaçados são os fios que tecem o juízo moral. Essa mistura aparece na seqüência, após a despedida de Tio Terêz: "Miguilim chorava um resto e ria, seguindo seu caminhinho" (p. 77). A fusão é projetada na fauna do entorno de matos por onde passa o menino, pois ele depara-se com “um caxinguelê (...) já de ah subindo p'la árvore de jequitibá, de reta só assim esquilando até em cima, corisco, com o rabãozinho bem esticado para trás, pra baixo, até mais comprido que o corpo" (p. 78). Difícil até ajuizar sobre o RABO do caxinguelê, se rabÃO ou rabozINHO, mais ainda se a conduta foi boa ou má. Empolgado com a aprovação de Tio Terêz, o menino quer contar tudo ao Dito, quase transformando o bem-feito no malfeito - se contasse, traria à tona o caso de Mãe com Terêz e seria desleal com o tio: "Agora via que nisso não tinha pensado: não podia contar ao Dito tudo a respeito do Tio Terêz, nem que ele Miguilim tinha sido capaz de não entregar o bilhete, e o que Tio Terêz tinha falado depois, de louvor a ele, tudo. Ah, aí Miguilim nunca pensou que ia penar tanto, por não dizer, cão de que tinha de ficar calado!" (p. 80). Se Deus vaquejou o pequeno inspirando-lhe a resposta ao Tio, agora o Arrenegado abóia-o atiçando-o para contar, embora Cão vincule-se aqui ao ter que "ficar calado". No entanto, dada a alta conta em que Miguilim tem Dito, gostaria de narrar-lhe o acontecido para dele ouvir louvor também. Percebendo que é dever silenciar, xinga, "cão de que tinha de ficar calado", pois é grande o seu querer de publicar o seu bem feito. Entretanto, publicar um feito tido como bem feito é torná-lo malfeito, segundo alguns sistemas éticos (como o Cristianismo). Cheiro de outras flores, diria Rosa.

Concluída a cena do bilhete, o conto narra outros acontecimentos: morte do Patorí, visita de Pai a séo Deográcias (pai de Patorí), chegada de Luisaltino e acidente, doença e morte do Dito - que ocupará o centro da narrativa. A morte de Dito completa o ciclo iniciado com o medo de Miguilim de morrer, depois da consulta de seo Deográcias. Com seu temor e com a morte real do irmão, o menino aprende o que é o morrer. A morte de Dito indica a impossibilidade de se encontrar na razão a regra para nosso agir (conforme pretendido por Kant). Isso porque o Dito é, dentre os personagens, o de maior esclarecimento. E ele morreu! É a hipótese levantada, em Buriti, por Miguel para a morte do irmão: “Dito, irmãozinho de Miguel, tão menino morto, entendia os cálculos da vida, sem precisar de procura. Por isso morrera? Viver tinha de ser um seguimento muito confuso." (p. 666). Viver não é fazer cálculos nem ser feliz é acertá-los. A morte de Dito mata em Miguilim a pretensão de estimar, antes de agir, o bem-feito ou o malfeito do ainda por fazer, negando-lhe a regra fixa que sempre busca. Também Kant, alegando a insuficiência da razão para calcular as conseqüências da ação empreendida para trazer à existência os objetos apetecidos 
pelas inclinações e julgados necessários ao nosso bem-estar, nega à busca da felicidade o estatuto de princípio supremo da moralidade.

O último aprendizado de Miguilim foi descobrir, com Rosa, o fracasso de querer buscar "algum sinal do Dito morto ainda no Dito vivo, ou do Dito vivo mesmo no Dito morto." (p. 105). Morto e vivo não se misturam. Clareia para Miguilim então a radicalidade que separa viver e morrer dos demais pares (feio/bonito, certo/errado). Aprendendo-o, alegra-se tanto que abraça Rosa. Entende que entre vida e morte a relação de temporalidade presente é a da sucessão, não a da simultaneidade:

Miguilim se agarrou com a Rosa, em pranto de alívio, aquela era a primeira vez que ele abraçava a Rosa. Mas a galinha choca vinha passando, com seus pintinhos, a Rosa mostrou-a a Miguilim. 'Uai, é a Pintadinha, Rosa? A Pintadinha também já tirou os pintos?' '- Mas já faz tanto tempo, Miguilim. Foi naqueles dias...' ‘- Que jeito que eu não vi?’ ‘ - Pois que você mesmo quis ver só foi a Pintinha-Amarela, Miguilim, por causa que ela tinha as três perdizinhas...' (p. 106).

Notícias das três perdizinhas chocadas pela Pintinha-Amarela eram sempre pedidas pelo Dito adoentado a Miguilim. A galinha até conseguiu chocar os ovos de perdiz, mas não conseguiu entremear perdizinhas a pintinhos - tanto quanto vivo e morto não existem simultaneamente. A morte das perdizinhas, estraçalhadas pelo mico estrela, indica a impossibilidade de se mesclar vida e morte; aqui há sucessão e não fusão ou reunião numa síntese maior. Miguilim aprende o mesmo que o menino de As margens da alegria, de Primeiras Estórias. Deslumbrado com a beleza do peru, o Menino de As margens entristeceu ao saber da morte do animal. Por ter "pensamentozinho ainda na fase hieroglífica" (ROSA, 1995a, p. 392) desconhecia que a morte de um indivíduo não carrega consigo a da espécie a que ele pertence; outros peruzinhos vieram e ainda que não fosse o mesmo, já era consolo: "Sua chegada e presença, em todo o caso, um pouco consolavam" (idem). Miguilim de início não entende que o morto não é (ou está) vivo e caça o Dito morto no Dito vivo; depois do diálogo com Rosa, compreende o impossível do seu "quererzinho ainda na fase hieroglífica": tal e qual o menino de As margens da Alegria, vendo um peruzinho suceder ao peru, o de Campo geral aceita a sucessão morte/vida. Peru e perdiz. As aves une-os e é com elas que os meninos aprendem o transitório e a sucessão da vida.

A elaboração do luto concluiu-a Mãitina: ensina que Dito "vinha em sonhos, acenava para a gente, aceitava louvor" (p. 106), chora com Miguilim, "Mãitina era pessôa para qualquer hora falar no Dito e por ele começar a chorar" (p. 106). Por fim, é sacerdotisa do ritual que arremata todo o luto: " $\mathrm{O}$ que eles dois fizeram, foi ela quem primeiro pensou. Escondido, escolheram um recanto, debaixo do jenipapeiro, ali abriram um buraco, cova pequena. De em de, camisinha e calça do Dito furtaram, para enterrar, com brinquedos dele." (idem). Mãitina é ex-escrava e suas práticas e palavras sempre foram desaprovadas por Vovó Izidra, que tachava-as de feitiçaria. Numa das visitas a Mãitina, Miguilim constata o infundado dos juízos de Vovó Izidra: “E, se agarrando nas costas dela, se abraçou com Mãitina. Ah, se lembrava. Pois porque tudo tinha tornado a se desvirar do avesso, de repente, Mãitina estava pondo ele no colo, macio manso, e fazendo carinhos, falando carinhos, ele nem esperava por isso". ( $p$. 
44). Agora, Mãitina "desvira do avesso" o juízo que Miguilim tem sobre o morrer, ajudando-o a continuar a vida sem o Dito.

Com Rosa e Mãitina Miguilim deixa de buscar no real do Dito morto (suas coisas, agora enterradas) o Dito vivo. Dito vive somente no simbólico, por meio de seus ditos e do que os outros falarão dele. Isso é marcado no conto no parágrafo seguinte ao do ritual desempenhado por Mãitina: “E um dia, então, de repente, quando ninguém mais não mandava nem ensinava, o Papaco-o-Paco gritou: “ - Dito, Expedito! Dito, Expedito!"[12] (p. 107). Miguilim pode agora prosseguir com sua vida, atendendo a demanda de Pai, formulada na seqüência: “ - 'Diacho, de menino, carece de trabalhar, fazer alguma coisa, é disso que carece!'” (idem). “Daí por diante não deixava [Pai] Miguilim parar quieto." (p. 108). Ainda tenta imitar Dito, "Mas não sabia imitar o Dito, não tinha poder." (idem). O dito de Rosa e o rito de Mãitina desviam Miguilim de identificar-se de modo mórbido (desejar ser o morto) a Dito. Ao invés de querer ser igual bastará a Miguilim lembrar-se do dito do Dito: “Na volta, em hora que ele estava mais tristonho e infeliz, foi-se lembrando de uma daquelas coisas que o Dito falava:" ( $p$. 113).

Dada essa atuação terapêutica das duas nesse momento, sentirá saudades somente delas no seu retiro na casa de Salúz: “Naqueles três dias, Miguilim desprezou qualquer saudade. Ele não queria gostar mais de pessôa nenhuma de casa, afora Mãitina e Rosa." (p. 120). O retiro é, ao pé da letra, um retirar-se da casa e da influência de Pai. Iniciado após uma briga com Pai, marca também o distanciamento do Dito: "Também não estava desejando se lembrar daqueles assuntos, dos conselhos do Dito." (idem). De retorno do retiro, recusa-se a cumprimentar o pai olhando-lhe nos olhos: "Tomou a benção, baixinho, surdo. Ficava olhando para o chão." (idem). A seqüência da narrativa não poderia ser mais eloqüente: o pai desfaz todos os brinquedos e o menino quebra os demais, dizendo assim da quebra dos laços de temor infantil que unia o menino ao Pai.

Seguem a doença de Miguilim (que o reaproxima de Pai) e sua cura por seo Aristeu; o assassinato de Luisaltino por Pai e o suicídio de Pai e, por fim, a chegada do doutor que lhe abre as vistas. Dos olhos, ao pôr-lhes os óculos; da mente, ao possibilitar-lhe ampliar o horizonte da vida com a ida para a cidade. No início do conto, a mãe reclamava do escuro do Mutúm: “Queixava-se, principalmente, nos demorados meses chuvosos, quando carregava o tempo, tudo tão sozinho, tão escuro, o ar ali era mais escuro" (p. 11). Mesmo escuro insistentemente destacado como característica do quarto de Vovó Izidra e do acrescente de Mãitina. Mãe queixava-se do escuro e agora ela abre no texto o significado do óculos do Dr. José Lourenço para além da correção oftálmica: “ - Vai meu filho. É a luz dos teus olhos, que só Deus teve poder para te dar. Vai." (p. 131). Fecha-se assim o ciclo aberto por Tio Terêz, ao levá-lo ao Sucurijú. Vovó Izidra enxergava no escuro; Mãitina mantinha sempre em seu acrescente um foguinho aceso: agora faz-se luz no escuro de Miguilim. Nas vistas e na cabecinha. Não é mais pitosgo. 


\section{Considerações finais}

Viagens nas obras de Guimarães Rosa dizem da mudança que se processa na vida dos personagens para além do simples deslocamento de espaço. Piscocartografia e não geografia. Em Campo geral, temos o protagonista viajando no início e no fim do conto e isso coincide com alterações profundas em sua vida: na primeira viagem, deixa pela primeira vez o Mutúm; na segunda, deixa-o para sempre - pois aí encerra-se o conto e o Miguel que reencontramos em Buriti, última narrativa de Corpo de baile, informa-nos que também a família deixara o lugar. Entre Campo geral e Buriti não há nenhum Campo particular ou Buriti intermediário, a relatar-nos a adolescência de Miguilim na cidade - a exemplo do feito por José Lins do Rego com Doidinho, termo médio entre o Carlos menino de Menino de engenho e o Carlos moço de Bangüê, ainda que Miguilim e Carlos façam o mesmo caminho, rural-urbano-rural.

No entanto, o desenvolvimento de Campo geral também narra viagem: Miguilim indo de um adulto a outro, de um dito a outro do Dito. Busca achar o que hoje sabemos não existir: um critério absoluto de julgamento que norteie nossas decisões e sirva de garantia de que o nosso juízo é universal e não um simples ponto avistado pela nossa vista do ponto onde estamos. Sem sair do Mutúm, Miguilim interpela Tio Terêz, Vovó Izidra, seo Deográcias, seo Aristeu, vaqueiros Jé e Salúz; visita Mãitina no acrescente, Rosa na cozinha; retira-se três dias na casa do vaqueiro Salúz; ouve relatos do Patorí e do Grivo, meninos que visitam o Mutúm; dialoga filosoficamente com Dito; aprende sobre Deus com Vovó Izidra e sobre o Demônio com o Dito.

Não sendo o cérebro a única organização capacitada para captar a realidade, Miguilim deseja apreendê-la por todas as vias disponíveis a ele no Mutúm: o catolicismo de Vovó Izidra e a religiosidade africana cultivada por Mãitina no puxadinho onde mora; a sabedoria dos vaqueiros e os rudimentos da tardia e sertaneja Aufklärung de seo Deográcias; as fala dos de dentro da casa (avó, pais, irmãos) e dos de fora que a ameaçam (Tio Terêz e Luisaltino); os conselhos dos adultos e as máximas do Dito; as cores e os cheiros do Mutúm. Ao consegui-lo, supera sua visão estreita de haver um modo só de enxergar a realidade e alonga seus olhos para a compreensão de que uma mesma realidade pode ser vista a partir de perspectivas diferentes, de que os juízos feio/bonito, malfeito/bem-feito se assentam em várias bases. Ou não tem nenhuma, pelo menos absolutamente. Amplia-se sua visão, metaforizada no óculos e na viagem da partida.

\section{Bibliografia}

ARAÚjO, Heloísa Vilhena. Teria Guimarães Rosa lido Nezami? In: Scripta, Belo Horizonte, v. 9. n. 17, 2005.

BARRETO, Lázaro. Manuelzão e Miguilim, de João Guimarães Rosa. In: Veredas de Rosa I. Belo Horizonte: PUCMinas, 2000.

CHRISTÓFORI, Luís Carlos \& SILVA, Francis Paulina Lopes da. Miguilim e o "peso de ser". In: Veredas de Rosa III. Belo Horizonte: PUCMinas, 2007.

FERNANDES, Fabiano. Per speculum in enigmate: Campo geral. In: Veredas de Rosa II. Belo Horizonte: PUCMinas, 2003. 
HUME, David. Tratado da natureza humana. São Paulo: UNESP/Imprensa Oficial do Estado, 2001.

KANT, Immanuel. Fundamentação da metafísica dos costumes. Lisboa: Edições 70, 1993.

LEITE, Dante Moreira. Campo geral. In: Psicologia e literatura. São Paulo: UNESP, 2002. MACHADO, Ana Maria. Recado do nome: leitura de Guimarães Rosa à luz do nome de seus personagens. Rio: Nova Fronteira, 2003, 3a ed.

MEIRELES, Cecilia. Viagem. In: Obra poética. Rio: Nova Aguilar, 1987.

PASSOS, Cleusa Rios Pinheiro. Os roteiros de Corpo de baile: travessias do sertão e do devaneio. In: Scripta. Belo Horizonte, v. 5, n. 10, 2002.

RÓNAI, Paulo. Rondando os segredos de Guimarães Rosa. Encarte da Edição Comemorativa 50 anos de Corpo de baile. Rio: Nova Fronteira, 2006.

ROSA, Guimarães. Corpo de baile. Rio: Nova Fronteira, 2006. Edição Comemorativa 50 anos.

Comemorativa 50 anos.

Grande Sertão: Veredas. Rio: Nova Fronteira, 2006. Edição . Correspondência com seu tradutor italiano. Rio: Nova Fronteira; Belo Horizonte: UFMG, 2003, 3a ed.

Aguilar, 1995.

. Diálogo com Guimarães Rosa. In: Fiç̧ão completa, v. 1. Rio: Nova

. Primeiras estórias. In: Fiç̧ão completa, v. 2. Rio: Nova Aguilar, 1995a.

SILVA, Daniela Silva da. Miguilim: a construção do ser-aí. In: ZILBERMAN, Regina (Org.). Corpo de baile: romance, viagem e erotismo no sertão. Porto Alegre: EDIPUCRS, 2007.

[1]

Sobre outros significados para o número sete em Corpo de baile, ver “Teria Guimarães Rosa lido Nezami", de Heloísa Vilhena de Araújo.

[2]

Em Os roteiros de Corpo de baile: travessias do sertão e do devaneio, Cleusa Rios Pinheiro Passos analisa Corpo de baile a partir da viagem. Quanto à partida de Miguilim no início de Campo geral a autora assim se posiciona: "A abertura da novela insinua expressivo índice da trama e do desenlace. Miguilim partirá com um doutor de fora que diagnostica sua 'vista curta', empresta-lhe óculos, esclarecendo-lhe a dificuldade de percepção dos contornos espaciais. A mediação especular do estrangeiro lhe permite, enfim, descobrir a beleza da região. Logo, as viagens maiores marcam o destino do personagem; a primeira (conduzida por Tio Terez e ligada ao sagrado, pois determinada pela crisma) gera lembranças e reforça o enigma que o persegue: o conhecimento do belo como contraposição aos castigos paternos e enfrentamento da morte do irmão predileto; a segunda aponta a ruptura da névoa visual, reiterando-se a metáfora do olhar; a apreensão do outro (seres e lugar) constitui como que um rito necessário à passagem do meio rural para o urbano onde novo ciclo principia: o contato com as letras, em outro universo cultural." (p. 81).

Vemos aqui dois problemas. Primeiro, a pesquisadora não desenvolve a afirmação inicial (de que a viagem da abertura do conto "insinua expressivo índice da trama e do desenlace"). Fica por conta do seu leitor continuar o texto. Segundo, embora se proponha a ler todo o Corpo de baile sob a ótica da viagem, não há nada mais no seu trabalho sobre Campo geral. Discordamos da rápida passagem pelo conto; dar conta do sentido da viagem nele exige maior exame das transformações vividas pelo protagonista e que se vinculam às suas viagens de um lugar a outro (à casa de Salúz, por exemplo, e que não é mencionada pela pesquisadora) e, num sentido figurado, também de um personagem a outro (as constantes indagações que Miguilim faz a todos de Campo geral).

[3]

Sobre o significado da viagem final, ver Per speculum in enigmate: Campo geral, de Fabiano Fernandes. Dos estudos sobre Campo geral revisados, este é o que mais se aproxima do nosso no que tange à seleção dos episódios submetidos à análise e, em alguns casos (desvio das vistas de Miguilim, dizer de seo Deográcias sobre saúde de Miguilim, luto de Miguilim pela morte do Dito, ritual de Mãitina e viagem do final), no modo mesmo de interpretá-los.

[4]

A cena dos bilhetes é sucintamente analisado por SILVA: "A dúvida: entregar ou não o bilhete. A personagem principia então um processo de reflexão sobre moral. Se entregar a carta para a mãe, vai contra o pai; se, por outro lado, não entregá-la, vai contra a amizade que tem pelo tio. Afinal, como agir? Como saber o que é certo ou errado? Ele resolve não entregar a carta, e os conflitos se dissipam." (p. 25). Dissipam-se com isso os comentários de Silva - em última instância, uma retomada do enredo mesmo do conto - acerca do episódio em que concentraremos boa parte de nossa análise. 
Equivocadamente, CRHISTÓFORI \& SILVA dão a frase como tendo sido um comentário do narrador após a morte do Dito: "Antes Dito era a referência para as suas dúvidas, sua busca de um sentido da vida. Agora, Miguilim teria que buscar nas experiências do dia-a-dia o que antes Dito lhe ensinava acerca da satisfação do viver. Nesse sentido, o narrador intervém na narrativa, comentando: 'Ele bebia um golinho de velhice". (p. 470). A afirmação é improcedente. O golinho de velhice bebeu-o Miguilim no episódio aqui analisado, ao compreender a insustentável leveza dos fundamentos em que assentam os juízos de quem aprova ou censura a conduta do outro e a não menor leveza em que se apoiam os critérios de quem decide proceder de um modo ou de outro.

[6]

Sobre a passagem, ver Manuelzão e Miguilim, de João Guimarães Rosa, de Lázaro Barreto. O autor cita exatamente o mesmo trecho que nós. Todavia, sua análise resume-se à frase que introduz a passagem: "Assim rendido aos encantos da verdade e da beleza sertanejas, Guimarães Rosa, versado nos altos saberes das filosofias de todas as épocas, apura os ouvidos na atenção e aprende com os boiadeiros e roceiros o que às vezes escapou a Platão e a Spinosa, como os ditirambos das páginas 74 e 75." (p. 349350).

No mínimo, seria necessário dizer o que há nos ditirambos e que escapara aos filósofos. Após o excerto de Guimarães, lê-se: “Mas o Dito possuía a sabedoria de quem vai morrer muito antes do tempo. Às vezes caçoava, às vezes falava sério, como quando interpreta o sentimento de culpa e o sofrimento das injustiças:". Nova citação de Rosa, confirmando que Barreto não se deteve no teor filosófico das perguntas de Miguilim e das respostas por ele obtidas, deixando assim uma lacuna em sua análise.

\section{[7]}

A ação pode ainda ser julgada desde um ponto de vista pragmático: se foi eficaz ou não em chegar ao fim para o qual ela constituía um meio. Uma ação, ainda que boa nessa perspectiva, pode carecer de valor moral; este reside em ela ser executada como um fim em si mesma, mesmo quando contraria o fim desejado pelas inclinações. Nos termos do filósofo: "todos os imperativos ordenam ou hipotética- ou categoricamente. Os hipotéticos representam a necessidade prática de uma acção possível como meio de alcançar qualquer outra coisa que se quer (ou que é possível que se queira). O imperativo categórico seria aquele que nos representasse uma acção como objetivamente necessária por si mesma, sem relação com qualquer outra finalidade." (KANT, 1993, p. 50).

[8]

Dada a importância da frase para nossa análise, cuidamos em cotejar o texto da Edição Comemorativa, publicado pela Nova Fronteira, com o da Ficção Completa de GR, da Nova Aguilar, e com o Manuelzão e Miguilim, da José Olympio (4a ed): a pontuação é a mesma. No trabalho de Lázaro Barreto, mencionado atrás, a pergunta a Jé é assim formulada: “Vaqueiro Jé: malfeito como é que a gente se sabe?". Nas referências bibliográficas consta a 17 ạ ed. de Manuelzão e Miguilim. Por essa pontuação, desfaz-se a afirmação de que algo é malfeito, mas continua valendo a impossibilidade (criada pelo "se" no meio da frase) de se interpretar como sendo uma pergunta sobre como saber o que é o malfeito.

[9]

Em O recado do nome, Ana Maria Machado considera Recado do morro, Cara de bronze, Buriti e Dãolalalão. Não analisa, portanto, Campo geral. Logo, a interpretação acima é associação livre nossa, a partir de nossas cadeias significantes, no sentido lacaniano.

[10]

A exemplo da pontuação, também aqui verificamos as edições da José Olympio e da Nova Aguilar, ambas com o plural no "quando".

[11]

Num dos poemas Canção do livro Viagem: “Nunca eu tivera querido / dizer palavra tão louca / bateume o vento na boca, / e depois no teu ouvido. // Levou somente a palavra, / deixou ficar o sentido. // O sentido está guardado / no rosto com que te miro (...)".

\section{[12]}

Em Miguilim e o "peso de ser", CHRISTÓFORI \& SILVA consideram os sons de Papaco-o-Paco como "recurso explorado por Rosa, para permitir conhecer o estado emocional da personagem. Desse modo, pode-se considerar que a fala do animal é, na verdade, mais uma ilusão auditiva da personagem do que uma profusão de falas aprendidas. Situando as intervenções do papagaio em diversos momentos do texto, percebemos que a pertinência das falas, forçosamente, nos leva à conclusão de haver uma intencionalidade do autor na utilização do recurso onomatopáico." Nesses "diversos momentos" não incluem a fala acima, não obstante concluam seu trabalho tratando das mudanças operadas no Miguilim pela morte do Dito. Perderam assim um forte reforço à sua tese. 